\title{
A Survey on Loanwords from English to Kurdish
}

\author{
Rebin Abdulqader Azeez", Hawkar Akram Awla ${ }^{2}$
}

Received: December 11, 2015 Accepted: December 22, 2015

\begin{abstract}
In this going-over study, words borrowed from English to Kurdish are scrutinized. More than 350 words are found to be derived from English to Kurdish as loanwords. In conformity with the wordlist which accompanies this research, the patterns of these words are categorized with reference to phonological-oriented criteria as assimilated, partially-assimilated, and non-assimilated borrowings. The assimilated genres were noticed to be the most frequently borrowed types of words from English to Kurdish. The meanings of each loanword from the donor (English) to the receiver language (Kurdish) are unchanged. However, the pronunciations of certain forms of loanwords are changed partly or naturalized. That is, the halfway assimilated loanwords may still be recognized as borrowings, but the non-assimilated ones are somewhat unrealizable.
\end{abstract}

Keywords: English language, Kurdish language, Sorani dialect, loanwords, borrowing

\section{Puxta}

Lam twěžinawa lěkolín amězadã, wŝa xwãstrãwakãn la ingliziyawa bo kurdi lěyãn dakoĺdrětawa. Zyãtr la 350 wŝa dadozrětawa ka la ingliziyawa hatuna nãw kurdi waku wuŝai xwãstrãw. Ba gwěrai aw lista wŝayai ka lagaĺ am twěžinawayadã dět, šěwazakãni am wŝãna polěn krãwn ba gwěrai pěwari tãibati fonoloji waku wŝai xwãstrãwi ĉunyak, nimĉa ĉnyak u nã ĉnyak. Ŝ̌̌wãza ĉunyakakãn wã těbini dakrãn kawã bãwtrin jori wŝai xwãstrãu bn la ingliziyawa bo kurdi. Manãi har wŝayakai xwãstrãw la zmãni baxŝar (inglizi) bo zmãni wargr (kurdi) nagorãwa. Harchanda, ŝěwãzi běžãni handě šěwai tãibati wŝa xwãstrãwakãn baŝěwai baŝi dagorěn yãxud ba xomãli dakrěn. Amaŝ manãi waya, wŝa xwãstrãwa nimĉaiya ĉunyakakãn lawãnaya heŝta har waku wŝai xwãstrãw sayir bkrěn, baĺam wŝa xwãstrãwa nãcunyakakãn tã rãdayak nazãnrãwn.

Paivin Saraki: zmani inglizi, zmani kurdi, diyalěkti sorani, wŝai xwastrawakan, xwastn.

$\underline{\text { Recommended citation: }}$

Azeez, R. A. \& Awla, H. A.(2016). A survey on loanwords from English to Kurdish. International Journal of Kurdish Studies 2 (1), pp.11- 28.

\footnotetext{
${ }^{1}$ Corresponding Author: Koya University/ English Language Department- Kurdistan Region of Iraq E-mail: rebin.abdulkadir@koyauniversity.org

${ }^{2}$ English Language Department, Koya University, Kurdistan Region of Iraq. E-mail: hawkar.akram@koyauniversity.org
} 


\section{INTRODUCTION}

Borrowing is one of the language change and language evolution related phenomena that subsists within every language around the world. Borrowing is explicated as word from one language that has been adapted for use in another (Nordquist, 2014: 1). This comes about when two languages interject socially, culturally, economically, or politically. Moreover, language itself is a means of communications, for this reason languages are used in order to maintain this goal of interaction in various ways. Languages are varied and are classified according to historical, geographical, cultural, and socio-economical facets and prospects. This has led to diversity in borrowing as an aspect of language use from a language to another.

Furthermore, one language may have words for which there are no equivalents in the other language. There may be words for objects, social, political, and cultural institutions and events or abstract concepts which are not found in the culture of the other language. It often occurs that one culture borrows from the language of another culture words or phrases to express technological, social or cultural innovations. For instance, English borrowings are entering languages everywhere, and in more domains than just science and technology (Nordquist, 2014: 2).

In conformity with Hassanpoor (1999: 10), Borrowing is a historical phenomenon; it is a product of different circumstances and plays different roles under changing situations. All languages change and borrowing is a dominant trend of language contact and change. The term 'borrowing' however usually implies a temporary transmission of possession to be followed by the return of the borrowed item at a later stage. But language borrowings are permanent. All components of language, from phonemes to words to grammatical structures, may be borrowed from one language to another.

\subsection{The problem}

Every language in this world has its own set of vocabulary. However, sometimes words from one language find their ways into the vocabulary of another language because these languages may have been in contact in one way or the other. When two or more languages come into contact with one another, borrowing may take place.

English language is seen as a central foreign language in Kurdistan region. Historically speaking, Kurdish language has been in contact with English when it became a prestigious language around the world. More specifically, this interaction became more prominent when England invaded Iraq and Kurdistan as northern part of the country exposed to that language in the long run. Later, English was entered in the process of teaching and learning English as a foreign language. Moreover, Media has played great role in using different vocabulary items from English into Kurdish language verbally and non-verbally.

For all that, a few studies have been conducted to explore the amount of loanwords from English to Kurdish. This current research only investigated the Iraq/Kurdistan part using 
Sorani dialect. Therefore, the present study is intended to survey about lexical borrowings from English to Kurdish.

\subsection{Aim and Significance}

This paper draws a bead on firstly, examining the loanwords from English to Kurdish. Secondly, it also puts forward an endeavor to establish a wordlist that compiles nearly all the loanwords from English to Kurdish.

This study addresses a worthful state of consideration that needs to be resolved. Thus, college students, EFL teachers, linguists, and researchers in the field can get benefit from the results of the study. That is, this survey study will allow everyone to inspect and see the extent to which English words are borrowed to Kurdish as their mother tongue.

\section{BACKGROUND}

\subsection{The Concept and Classification of Borrowing}

Every language in this world has its own set of lexical items. However, sometimes lexical items appear in the vocabulary of another language due to the possible contact of the two languages. When two or more languages encounter each other, borrowing may occur (Marjie-Okyere, 2013). Crystal (1985:36) defines borrowing as "linguistics forms being taken over by one language or dialect from another. Similarly, Hudson (1980) regards borrowing as the linguistics process that requires taking words from a language into another.

Haugen (1950) classifies borrowing into two main types: importation and substitution. The former involves taking a pattern into a language while the former latter involves replacing something in another language with a native pattern. He further sub-classifies borrowing into loanwords, loan blends and loan shits. Loanwords require the importation of form and meaning with levels of phonological replacement which may take place as none, partial, or complete replacement of the borrowing form. Loan blends entails a combination of both foreign and native forms, in which there is only partial morphemic importation. That is to say, a native morpheme has been replaced by part of the foreign word.

Loan shifts involves the representation of a foreign concept by a native form. Haugen further classifies loanwords on the basis of oral borrowing into unassimilated, partially assimilated and wholly assimilated loanwords.

Hassanpoor (1999) applies Haugens' division of loans to classify loans in Sorani as loanwords, loan blends and loan shifts. Hassanpoors' study “A Study of European, Persian and Arabic Loans in Sorani" is the most comprehensive study ever conducted on loans in Sorani. Various words can be seen in Kurdish Sorani dialect which were borrowed from different languages such as Arabic, Persian, English, and Turkish. Yildiz and Akbarov (2012) examined the borrowed words from Turkish which have directly or indirectly been borrowed. Moreover, Sadiq (2011) indicates that the Kurdish word babe has directly been taken from the English word babe. There is a dearth of research on Sorani loanwords that have been taken from English. It is hoped that this study can fill the gap from this respect. 


\subsection{Some Motivations for Borrowing}

Despite of defining and classifying the borrowing phenomenon, linguists have attempted to identify the motivations that lead someone to borrow words from another language. The most popular motivations for word borrowing as Durkin (2009) states are the need and prestige. The former occurs when a new concept or thing is discovered which already has a name in the donor language but not in recipient language. For example, the word kompeter has been borrowed from English because the computer was first invented by an English person. The latter takes place when a speaker feels that there is greater social cachet connected with a word from another language. English as prestigious languages has become the main source of borrowing for other less prestigious languages including Kurdish. Bloomfield (1984, in Newman, 2002) is of the opinion that usually a subordinate language mostly borrows from a dominant one.

Bloomfield (1933, in Mohammed, 2009) indicates that political-social conditions such as colonization, war, conquest, and migration results in the dominance of one language over the other. Thus, the rapid advances in technology and other facets of life such as colonization might have forced Kurdish to borrow words from the English language. The colonization of Iraq by Britain may have led to the borrowing of some English words by Kurds. The US- led invasion might also have resulted in borrowing some English words by Kurdish speakers.

Media whether spoken or written is another factor which affects borrowing (MarjieOkyere, 2103). Sabir (2013) examined the increasing use of English loan words in political programs at visual media in Kurdistan region and found out that announcers, reporters, and editors prefer to use English to Kurdish equivalents due to their lack of knowledge of Kurdish equivalents, modernity and better image, prestigiousness, the length of the Kurdish terms, for varying the vocabulary, and for showing off.

\subsection{English and Kurdish}

In conformity with Stokes, Gorman, and Newman (2009: 281), Kurdish is of the northwestern subgroup of those Iranian languages related to the Indo-Iranian branch of the Indo-European languages. The original language of the area was Hurrian, they are as far apart from each other as German and English. Accordingly, they may also be referred to as distinct languages in their own right. In addition, both Kurmanji and Sorani encompass a large number of regional and local dialects and sub-dialects, although speakers of these dialects usually can understand each other. The other forms of Kurdish language are Gorani and Zaza. The former is spoken in southern Kurdistan and Kermanshah in Iran as well as the Halabja region of Iraqi Kurdistan and in the Hewraman Mountains bordering Iran and Iraq. The latter is spoken in the northwest parts of Kurdistan.

Furthermore, many endeavors to create a standard written language or to bridge the gap between Kurmanji and Sorani have not been successful. The two have developed almost independently of each other. Sorani, for example, is dominant for its having been the language of the city of Suleymaniya and Erbil, now in the north of modern Iraq, founded in the 18th 
century by the Baban state, a Kurdish state in the Zagros Mountains. From the late 19th century Kurdish intellectuals began writing in Kurmanji. Sorani developed mainly as the language of poetry until the fall of the Ottoman Empire early in the 20th century (Stokes, et al, 2009: 282).

Depending on English language Club Website (2014), English is a member of the Germanic family of languages. Germanic is a branch of the Indo-European language family. Additionally, according to Merriam-Webster Online Dictionary (2014), the history of English is conventionally, divided into three periods called Old English (or Anglo-Saxon), Middle English, and Modern English. The earliest period begins with the migration of certain Germanic tribes from the continent to Britain in the fifth century A.D., and it continues until the end of the eleventh century or a bit later. The period of Middle English extends roughly from the twelfth century through the fifteenth. The influence of French and Latin upon the lexicon continued throughout this period. The period of Modern English extends from the sixteenth century to our own day.

Other important early developments include the stabilizing effect on spelling of the printing press and the beginning of the direct influence of Latin and, to a lesser extent, Greek on the lexicon. Later, as English came into contact with other cultures around the world and distinctive dialects of English developed in the many areas which Britain had colonized, numerous other languages made small but interesting contributions to its word-stock (Merriam-Webster OD., 2014).

Nowadays, American English is particularly influential, due to the USA's dominance of cinema, television, popular music, trade and technology (including the Internet). But there are many other varieties of English around the world, including for example Australian English, New Zealand English, Canadian English, South African English, Indian English and Caribbean English (English Club Website-History of English language, 2014).

With references to Durkin (2014), during the medieval and early modern periods the influence of English spread throughout the British Isles, and from the early seventeenth century onwards its influence began to be seen throughout the world. The complex processes of exploration, colonization and overseas trade that characterized Britain's external relations for several centuries led to significant change in English. Words were derived from all over the world through the languages of other trading and imperial nations such as Spain, Portugal and the Netherlands. In the meantime, new varieties of English emerged, each with their own vocabulary and grammar and their own distinct pronunciations. More recently still, English has become a lingua franca, a global language, regularly used and understood by many nations for whom English is not their first language.

By the same token, the life of loanwords in Kurdish is, among others, the story of the transformation of a pre-modern society, the division of Kurdistan among four nation-states, domination and subordination, the rise of Kurdish nationalism, modernization and standardization of the language (Hassanpoor, 1999: 10). 


\section{METHODOLOGY}

\subsection{Instrument}

In the present survey study, the researchers depended on a wordlist in order to collect the data. First, an English- Kurdish dictionary by Karadaghi (2006) is used to identify and illustrate all the vocabulary items (words) that are taken from English to Kurdish. That is, the words which are collected form the aforementioned dictionary were thought to be borrowed in certain ways from English to Kurdish. Later, the types of the loanwords were identified according to the conventions of borrowing from a language to another. The vocabulary items (see appendix: A) are all listed alphabetically. The researchers used the list to highlight loanword types and to show the variety of words taken from English to Kurdish language.

\subsection{Data Collection}

The data collection procedure in this current study is done by looking closely into a wordlist based on an English- Kurdish dictionary by Karadaghi (2006) for the loanwords from English to Kurdish.

\subsection{Data Analysis}

In the analysis of the collected data which are later converted into a wordlist of English loanwords to Kurdish language, the researchers tried to inspect and explore the types of borrowing and make sure if the words are used in formal or informal Kurdish language. Later, the researchers validated the wordlist in collaboration with Kurdish Department/Koya University teaching and language expert staff to see the validity and reliability of the English loanwords to Kurdish that were collected during the study. The staff was comprised of two $\mathrm{PhD}$ holders in Kurdish language (linguistics branch) who were teachers in the mentioned context. They investigated the wordlist thoroughly and confirmed that the established wordlist is a proper raw material to see the amount of English loanword to Kurdish and to explicate the types of borrowing from the donor to the hosting language.

\section{RESULTS AND DISCUSSION}

The results in the present study confirm that loanwords from English language to Kurdish vary depending on the patterns of borrowing from the donor to the recipient language. That is, the way a word or phrase is borrowed can be classified into two major distinctive patterns, namely, importation and substitution. The former denotes that a word is borrowed without changing in meaning and sound, while the latter represents a borrowing which replaces something from the donor with a native pattern in the receiver.

In conformity with Muhammad (2009), the findings in this study can be further classified into three phonological-based patterns that represent certain oral borrowing features. In other words, the loanwords which were collected by the researchers of the present 
study are found to be classified into assimilated ${ }^{l}$, partially assimilated ${ }^{2}$, and non-assimilated ${ }^{3}$ borrowings. The total number of gathered loanwords is 358 words that are enlisted in the wordlist, see appendix (A). The assimilated pattern of an English loanword is recognized as a word that is borrowed by speakers of the recipient language as it is pronounced in its original donor form. Partially assimilated English loanwords are produced with the partial substitution of a sound with a vowel or a consonant. Non-assimilated English loanwords, however, are words which were produced by the recipient users totally differently from the original English word.

For instance, the words academy, band, canal, dance, feedback, gallery, helicopter, idiom, keyboard, logic, mall, normal, organ, page, quiz, robot, sample, tanker, vitamin, wrong-side, and zigzag are assimilated loanwords from English to Kurdish. That is, these borrowed words are brought to Kurdish without changes in meaning and pronunciation. According to the results, 196 loanwords were selected as assimilated patterns. Concerning the partially-assimilated loanwords, the researchers pointed out 128 patterns that are brought into Kurdish with changes in pronunciation. The borrowed words were being modified by replacing with a vowel or a consonant in the receiver language such as, agency, balloon, cable, dialogue, expire, fault, game, heater, film, jacket, karate, lamp, massage, opposition, hello, passport, restaurant, satellite, telephone, and wire. However, the non-assimilated loanwords are lesser than other patterns in number which were about 34 patterns being borrowed into Kurdish with entirely distinct states such as, automobile, biscuit, bulldozer, cigarette, dashboard, giraffe, jeep, kettle, machine, pliers, samovar, and toilet. See Table 1 for phonologically-based loanwords with distinct features and total numbers per each pattern.

Table 1: Classifications of Loanwords from English to Kurdish

\begin{tabular}{|c|c|c|c|c|c|c|}
\hline N & \multicolumn{2}{|c|}{ Assimilated $^{l}$} & \multicolumn{2}{c|}{ Partially-assimilated $^{2}$} & \multicolumn{2}{c|}{ Non-assimilated $^{3}$} \\
\hline$>$ & E & K & E & K & E & K \\
\hline 1 & Address & Drěs & Battery & patri & Budget & Buja \\
\hline 2 & Album & Album & Bottle & bitíl & Pliers & Playis \\
\hline \multicolumn{2}{|c|}{196} & \multicolumn{2}{c|}{128} & \multicolumn{2}{c}{34} \\
\hline
\end{tabular}

The results in the current study suggest that assimilated categories outnumber other loanword types. In other words, the words that are borrowed from English to Kurdish were mostly unchanged in terms of meaning and pronunciation. However, there are English words being adopted by Kurdish speakers into either semi-changed or completely changed forms. For instance, the borrowed words ozone, palace, scanner, melody, and disk are assimilated sets of loanwords with similar pronunciation in the receiver language. However, the word gear as a semi-assimilated genre, its sound transcription in English is /girr/ that is changed in Kurdish. The vowel sound /ra/ was replaced with /3:/ as Kurdish speakers pronounce the word as /g3:r/. For the latter type, non-assimilated loanwords that were entirely adopted into distinct shapes; a word like giraffe is phonologically changed into a different one. 
Its English pronunciation form /jə- ra:f/ is changed in Kurdish to /z^rra:fə/. Check appendix (A) for the list of loanwords from English to Kurdish.

It can be further illustrated that the majority of the loanwords were being adopted into Kurdish from English without changing the semantic or meaning facet of the words. That is to say, the meanings that are associated with each single word in the donor language are similar to the meanings that are found in the receiver language. The alteration or modification of the loanwords is only detected in the phonological aspects of the words. Although the pronunciation is changed, the meaning is still the same. For instance, the loanwords automatic, chance, boycott, disco, gender, heater, motel, freezer, mixer, protest, syringe, routine, tactic, laser, quiz, load, and nylon are all convey similar meanings in both donor and receiver languages. Their pronunciations, however, are changed accordingly.

Furthermore, some words like budget, toilet, democracy, carnival, automobile, ambulance, as demonstrated in Merriam-Webser dictionary (2014) might have been adopted from French and Latin to Kurdish but via English. That is, these words are derived to English frist then borrowed by Kurdish due to the colonization of Kurdistan by British empire in past. Kurds had direct contact with British invaders and they did not have such contact with French language. So, the possibility of borrowing from English to Kurdish seems to be stronger than the possibility of borrowing from French to Kurdish.

\section{CONCLUSION}

In the current study, it can be concluded that loanwords from English as a donor language to Kurdish as a recipient language are noticeably importations and substitutions. The importation categories are the ones that the pronunciation and meaning of the donor words are similar to the recipient language versions. The substitution patterns are changed words from donor to the recipient language in either partially assimilated or non-assimilated types. The assimilated loan-words comprise the majority of the word-items inputted within the attached wordlist.

\subsection{Implications}

In conformity with the results in the present study, supported by the findings and the research design, the researchers confirm implementing certain strategies and principles in order to teach English vocabulary to Kurdish EFL learners. These procedures can be rendered in several technical inside and outside classroom activities performed by students and monitored by the teachers. Over and above that, some suggestions and recommendations are given below which may help teachers and students in teaching and learning English vocabulary.

- The teacher should consider that quite a number of words are borrowed from English to Kurdish. Students need to be aware of this. In teaching EFL vocabulary items, teachers should render ways to show how common English words are with Kurdish ones. This will enable students to learn new words of English more enthusiastically.

- The teacher should make the learners to attach importance to the foreground of English high frequent vocabulary items in both learning and in articulating with the 
language. This can also be done when monitoring learners' learning procedures to guide them find words in English that moved to Kurdish as loanwords.

- Teachers should use an instructional method to highlight what students know and what they want to know in English vocabulary through using borrowed word-items from English to Kurdish. This facilitates their learning as they notice that the some words in Kurdish are derived from English.

- Teaching and learning EFL can further be harmonized through finding matching points between the students' native language with English via using word-lists consisting of loanwords, or any other language related elements.

- A dictionary of loanwords from English to Kurdish is significantly necessary to be established for recording all the words borrowed from English to Kurdish so that institutions like university, schools, language centers, and research centers can get benefit from.

\subsection{Suggestions}

To find out more words and phrases that Kurdish borrowed from English, further research is needed. This can be done in a bigger design of a study. Moreover, a dictionary of loanwords from English to Kurdish is absolutely significant as students, teachers, and researchers can use it to enhance learning, strengthen teaching process, and carry out more researches. An etymological analysis of words borrwed from English to Kurdish is needed due to the fact that some words occure in more than a dialect of Kurdish such as drop (dlopa ${ }^{3}$ ) wich occurs in both Sorani and Kurmanji dialects. Eventually, some words might have been taken from another language rather than English to Kurdish. This will lighten the path for other reaerch attempts to know more about loanwords.

\section{REFERENCES}

Crystal, D. (1985).A Dictionary of Linguistics and Phonetics, London: Routledge.

Durkin, P. (2104). Borrowed Words: A History of Loanwords in English. Oxford: OUP.

Durkin, Philip. (2014). The History of English: Five Events that Shaped the History of English. Retrieved online from http://www.oxforddictionaries.com/words/the-historyof-english. on 26-4-2014.

English Language Club. History of the English Language: What is English? A short history of the origins and development of English. (2014). Retrieved online from http://www.englishclub.com/english-language-history.htm, on 26-4-2014

Hassanpoor, J. (1999). A Study of European, Persian and Arabic Loans in Standard Sorani. Reports on Asian and African Studies (RAAS)1. XXpp. Uppsala. ISBN 91-506-13537.

Hudson, R.A. (1980). Sociolinguistics. Cambridge: Cambridge University Press. 
Haugen, E. (1950). The Analysis of Linguistic Borrowing. Language, 26, 210-231.

Karadaghi, R.( 2006). The Azadi (English-Kurdish) Dictionary. Iran: Ehsan Publishing House.

Marjie-Okyere, S. M ( 2013). Borrowings in Texts: A Case of Tanzanian Newspapers. New Media and Mass Communication, 16, 1-8.

Merriam-Webster OD. What are the origins of English language? (2014). Retrieved online from http://www.merriam webster.com/help/faq/history.htm, on 26-4-2014.

Mohammed, S. M. (2009). English Loanwords in the Iraqi Arabic Dialect. MA thesis, University of Malaya Kuala Lumpur, Malaysia. Retrieved online on June, 9, 2012 from http://studentsrepo.um.edu.my/1926/1/Abstract.pdf

Newman, D. L. (2002): The European influence on Arabic during the Nahda : lexical borrowing from European languages (ta rib) in 19th-century literature. Arabic Language and Literature, Vol. 5, No. 2, pp. 1-32.

Nordquist, R. (2014). Borrowing. Downloaded form http://grammar.about.com/od/ab/g/borrowingterm.htm, on 22-4-2014, at 12:35 pm.

Stokes, J., Gorman, A., \& Newman, A. (2009). Encyclopedia of the Peoples of Africa and the Middle East. New York: InfoBase Publishing, Inc.

Sadiq, F. O. (2011). La Daikbwny Wîe (The Birth of Words). Sulaimani: Shvan Publishing House.

Sabir, P. H. (2013). Increasing the use of loan words in the performance of Kurds in political programs at visual media. Journal of Zankoy Sulaimani, Part B. No. 39.

Yildiz, N.and Akbarov, A. (2012). Borrowing words from Turkish to Kurdish. Global Advanced Research Journal of Management and Business Studies, 1(11), 245-247. 
APPENDIX A: Borrowed Wordlist: Loanwords from English to Kurdish

ليستى وشه كانى وه ركيراو له ئينعليزى بوّكوردى

\begin{tabular}{|c|c|c|c|c|c|}
\hline $\mathbf{N}$. & English & Kurdish & N. & English & Kurdish \\
\hline 1 & Academy & Akãdimi $^{l}$ & 24 & Balance & Bãlãns ${ }^{l}$ \\
\hline 2 & Actor & Aktar $^{2}$ & 25 & Balcony & Balkoni $^{2}$ \\
\hline 3 & Acetone & Asi:ton ${ }^{l}$ & 26 & Balloon & Bãlon² \\
\hline 4 & Address & Adrěs $^{l}$ & 27 & Band & Bãnd $^{l}$ \\
\hline 5 & Again & Agěn ${ }^{l}$ & 28 & Bandage & Bãndij ${ }^{l}$ \\
\hline 6 & Agency & ${\text { Ǎz̃ãns }{ }^{2}}^{2}$ & 29 & Bank & Bãnk $^{l}$ \\
\hline 7 & Agenda & Ajěndã $^{2}$ & 30 & Bar & Bãr ${ }^{l}$ \\
\hline 8 & Air condition & Eyar kondiŝn ${ }^{2}$ & 31 & Baseball & Baisbolíl \\
\hline 9 & Album & Album ${ }^{l}$ & 32 & Basket & Bãskět $^{l}$ \\
\hline 10 & Alternative & Altarnatif $^{2}$ & 33 & Battery & Pãtri $^{2}$ \\
\hline 11 & Aluminum & Alaminyom $^{2}$ & 34 & Beer & $\mathrm{Bi}: \mathrm{ra}^{2}$ \\
\hline 12 & Ambulance & Ambulãns $^{2}$ & 35 & Benzene & Banzi:n ${ }^{l}$ \\
\hline 13 & Archive & Arŝi: $f^{2}$ & 36 & Bicycle & Pãski: $1^{3}$ \\
\hline 14 & Aristocrat & Aristkorã $t^{2}$ & 37 & Billiard & Bilyãrd $^{2}$ \\
\hline 15 & Assurance & Aŝurans ${ }^{l}$ & 38 & Billion & Bilyon $^{3}$ \\
\hline 16 & Atlas & Atĺas $^{l}$ & 39 & Biology & Bãyaloji $^{2}$ \\
\hline 17 & Atom & Atom $^{l}$ & 40 & Biscuit & Pskit $^{3}$ \\
\hline 18 & Automatic & Otomãti:k ${ }^{2}$ & 41 & Blacklist & Blãkli:st ${ }^{l}$ \\
\hline 19 & Automobile & Otombel $^{2}$ & 42 & Block & Blok $^{l}$ \\
\hline 20 & Baby & $\mathrm{Baba}^{3}$ & 43 & Bluetooth & Blutus $^{2}$ \\
\hline 21 & Background & Bakgrãwand $^{l}$ & 44 & Bodyguard & Bodigãrd $^{l}$ \\
\hline 22 & Bacteria & Baktiryã $^{2}$ & 45 & Bomb & Bomb $^{l}$ \\
\hline 23 & Badge & Bãjl & 46 & Bond & Bond $^{l}$ \\
\hline
\end{tabular}




\begin{tabular}{|c|c|c|c|c|c|}
\hline N. & English & Kurdish & N. & English & Kurdish \\
\hline 47 & Box & Boks $^{l}$ & 72 & Carton & Kãrton ${ }^{l}$ \\
\hline 48 & Boycott & Bãykot $^{l}$ & 73 & Case & Kayis $^{l}$ \\
\hline 49 & Brake & Brěk $^{2}$ & 74 & lassic & Klãsi:k ${ }^{l}$ \\
\hline 50 & Bronze & Bronz $^{l}$ & 75 & Card & Kãrt $^{2}$ \\
\hline 51 & Brow & $\mathrm{Bro}^{2}$ & 76 & Carnaval & ${\text { Karnavã }{ }^{2}}^{2}$ \\
\hline 52 & Budget & Buja $^{3}$ & 77 & Cash & $\mathrm{Kã̃}{ }^{l}$ \\
\hline 53 & Bulldozer & Bindozar $^{3}$ & 78 & Catalog & Katalog $^{2}$ \\
\hline 54 & Bureaucracy & Birokrãsi $^{3}$ & 79 & Catholic & Kãsoli:k² \\
\hline 55 & Bus & Pãs $^{3}$ & 80 & Caviar & Kaviyãr $^{l}$ \\
\hline 56 & Business & Biznis $^{l}$ & 81 & Censor & Sãnsor $^{2}$ \\
\hline 57 & Cable & Kěblí & 82 & Center & Santar $^{2}$ \\
\hline 58 & Cacao & Kakãw $^{2}$ & 83 & Chance & $\hat{\text { Cãns or } \hat{S}^{\prime}{ }^{l}}$ \\
\hline 59 & Café & Kãfěl & 84 & Channel & Kanã $^{2}$ \\
\hline 60 & Cafetería & Kaftiryã $^{2}$ & 85 & Character & Kãraktar ${ }^{l}$ \\
\hline 61 & Cake & Kěk $^{2}$ & 86 & Chemical & Kimyãyi $^{2}$ \\
\hline 62 & Calendar & Kãlěndar ${ }^{l}$ & 87 & Cheque & $\hat{\text { Sik or } \hat{C a k}^{2}}$ \\
\hline 63 & Calorie & Kãlori ${ }^{l}$ & 88 & Cigarette & Jigara $^{3}$ \\
\hline 64 & Camera & Kãměral & 89 & Cinema & Si:namã ${ }^{l}$ \\
\hline 65 & Canal & Kanãlíl & 90 & Civil & Svi:12 \\
\hline 66 & Canary & Kanãri $^{l}$ & 91 & Class & KÍãs ${ }^{l}$ \\
\hline 67 & Candidate & Kãndid $^{3}$ & 92 & Clinic & Klini:k ${ }^{l}$ \\
\hline 68 & Canton & Kãnton ${ }^{2}$ & 93 & Clip & Klip $^{l}$ \\
\hline 69 & Capsule & $\mathrm{Kapsul}^{2}$ & 94 & Cobra & Kubra $^{2}$ \\
\hline 70 & Caravan & Karavãn ${ }^{l}$ & 95 & Coca & Koka $^{2}$ \\
\hline 71 & Carbon & Kãrbon ${ }^{l}$ & 96 & Code & $\operatorname{Kod}^{l}$ \\
\hline
\end{tabular}




\begin{tabular}{|c|c|c|c|c|c|}
\hline N. & English & Kurdish & N. & English & Kurdish \\
\hline 97 & Cola & Kolã $^{l}$ & 122 & Data & Datã $^{2}$ \\
\hline 98 & College & Koli:j ${ }^{l}$ & 123 & Daughter & $\operatorname{Dot}^{3}$ \\
\hline 99 & Coma & Komã $^{l}$ & 124 & Dance & Dãns $^{l}$ \\
\hline 100 & Comedy & Komidi ${ }^{l}$ & 125 & Dashboard & Daŝbul $^{3}$ \\
\hline 101 & Committee & Komi:ta ${ }^{2}$ & 126 & Debate & Debait $^{l}$ \\
\hline 102 & Company & Kompãnyã ${ }^{2}$ & 127 & Decorate & Di:kor ${ }^{3}$ \\
\hline 103 & Compressor & Komprěsar $^{2}$ & 128 & Democracy & Dimukrãsi $^{2}$ \\
\hline 104 & Concrete & Konkri:t ${ }^{l}$ & 129 & Democrat & Dimukrãt $^{l}$ \\
\hline 105 & Conference & Konfrãns $^{2}$ & 130 & Demography & Di:mogrãfi ${ }^{l}$ \\
\hline 106 & Congress & Kongrěs $l$ & 131 & Deport & Di:port ${ }^{l}$ \\
\hline 107 & Comment & Koměnt $^{2}$ & 132 & Design & Di:zayin ${ }^{l}$ \\
\hline 108 & Communist & Komonist $^{2}$ & 133 & Diagram & Dayãgrãm $l^{l}$ \\
\hline 109 & Consulate & Kunsul $^{3}$ & 134 & Dialect & Dãyalekt $^{2}$ \\
\hline 110 & Contract & Kontrãkit $l$ & 135 & Dialogue & Diyãlog $^{2}$ \\
\hline 111 & Control & Controlíl & 136 & Dictator & Dictãtor $^{2}$ \\
\hline 112 & Copy & $\mathrm{Kopi}^{l}$ & 137 & Dinosaur & Dãinãsor $^{2}$ \\
\hline 113 & Corner & Kornar $^{l}$ & 138 & Diploma & Diblom $^{2}$ \\
\hline 114 & Couple & Kapíl & 139 & Disco & Di:sko ${ }^{l}$ \\
\hline 115 & Course & Kors $^{l}$ & 140 & Disk & Disk $^{l}$ \\
\hline 116 & Cowboy & $\mathrm{Kãbo}^{2}$ & 141 & Doctor & Diktor $^{2}$ \\
\hline 117 & Crane & Krěn $^{2}$ & 142 & Document & Dokyuměnt $^{l}$ \\
\hline 118 & Cream & Krěm $^{l}$ & 143 & Dollar & Dolãr ${ }^{l}$ \\
\hline 119 & Crystal & Kri:stãl ${ }^{l}$ & 144 & Dolphin & Dolphin $^{l}$ \\
\hline 120 & Culture & Kaltur $^{3}$ & 145 & Domino & Domina $^{2}$ \\
\hline 121 & Dagger & $\operatorname{Daga}^{2}$ & 146 & Dossier & Dosya $^{2}$ \\
\hline
\end{tabular}




\begin{tabular}{|c|c|c|c|c|}
\hline N. $\quad$ English & Kurdish & N. & English & Kurdish \\
\hline 147 Double & Dabíl ${ }^{l}$ & 172 & Fuse & Fiyuz $^{l}$ \\
\hline 148 Drama & Drãmã $^{l}$ & 173 & Gallery & Galari $^{l}$ \\
\hline 149 Drill & Drěl $^{2}$ & 174 & Gallon & Gãlon ${ }^{l}$ \\
\hline 150 Drop & Díopa $^{3}$ & 175 & Game & Gama $^{2}$ \\
\hline 151 Dynamic & Dãinãmi:k ${ }^{l}$ & 176 & Garage & Garãj $^{2}$ \\
\hline 152 Dynamo & Dynamo $^{l}$ & 177 & Gear & Gěr ${ }^{2}$ \\
\hline 153 Expire & Ekspãyar $^{2}$ & 178 & Gender & Jěndar $^{l}$ \\
\hline 154 Factor & Fãktar $^{l}$ & 179 & Geography & Jugrãfi $^{3}$ \\
\hline 155 Fantasia & Fãntãzyã ${ }^{l}$ & 180 & Geology & Jiyoloji $^{l}$ \\
\hline 156 Fashion & Fãŝn ${ }^{l}$ & 181 & Giraffe & Zarãfa $^{3}$ \\
\hline 157 Fault & Falit $^{2}$ & 182 & Goal & Golil \\
\hline 158 Federal & Fidrã $^{2}$ & 183 & Gorilla & Gorila $^{2}$ \\
\hline 159 Feedback & Fidbãk $^{l}$ & 184 & Guarantee & Garanti ${ }^{l}$ \\
\hline 160 File & Fãyil $^{l}$ & 185 & Guerilla & Gari:lã ${ }^{2}$ \\
\hline 161 Film & Flim $^{2}$ & 186 & Guitar & Gitãr $^{l}$ \\
\hline 162 Final & Fãynãl-finaĺ² & 187 & Gymnastic & Jumnãsti:k ${ }^{2}$ \\
\hline 163 Filter & Fltar $^{l}$ & 188 & Hack & Hãk $^{l}$ \\
\hline 164 Fit & Fi: $t^{l}$ & 189 & Hacker & Hãkarl $^{l}$ \\
\hline 165 Fitter & Fi:tar ${ }^{l}$ & 190 & Harass & Harãsãn ${ }^{2}$ \\
\hline 166 Flash & Flãŝ $^{l}$ & 191 & Harmony & Harmoni ${ }^{l}$ \\
\hline 167 Flat & Flãa $t^{l}$ & 192 & Heater & Hi:tar ${ }^{2}$ \\
\hline 168 Folklore & Folklor $^{l}$ & 193 & Helicopter & Helikoptar $^{l}$ \\
\hline 169 Form & Form $^{l}$ & 194 & Hello & Halaw $^{2}$ \\
\hline 170 Freezer & Frězar $^{2}$ & 195 & Heroin & Hiroyi:n ${ }^{l}$ \\
\hline 171 Frequency & 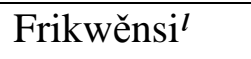 & 196 & Horn & Horn $^{l}$ \\
\hline
\end{tabular}




\begin{tabular}{|c|c|c|c|c|c|}
\hline N. & English & Kurdish & N. & English & Kurdish \\
\hline 197 & Hydrogen & Hãydroji:n ${ }^{l}$ & 222 & Mechanic & Mikãni:k ${ }^{l}$ \\
\hline 198 & Hotel & Hotěl $^{l}$ & 223 & Mechanism & Mikãnizm $^{2}$ \\
\hline 199 & Hysteria & Histirya $^{2}$ & 224 & Medal & Madalyã ${ }^{3}$ \\
\hline 200 & Idea & Adiya $^{l}$ & 225 & Media & Mi:dyã ${ }^{l}$ \\
\hline 201 & Idiom & Idyom $^{l}$ & 226 & Melody & Milodi ${ }^{l}$ \\
\hline 202 & Imperialism & Imperyãlizm $^{l}$ & 227 & Microphone & Mãikrofon $^{2}$ \\
\hline 203 & Jeep & $\mathrm{Jěb}^{3}$ & 228 & Militia & Mili:ŝya ${ }^{l}$ \\
\hline 204 & Jacket & Ĉãkat $^{2}$ & 229 & Millionaire & Milyoner $^{2}$ \\
\hline 205 & Karate & Kãrãti ${ }^{2}$ & 230 & Mixer & Mixar $^{l}$ \\
\hline 206 & Ketchup & $\mathrm{KěCap}^{l}$ & 231 & Mobile & Mobãyil $^{l}$ \\
\hline 207 & Kettle & Kitri $^{3}$ & 232 & Model & Modi: $1^{2}$ \\
\hline 208 & Keyboard & Kibord $^{l}$ & 233 & Modern & Moděrn $^{l}$ \\
\hline 209 & Lamp & Lãmpã ${ }^{2}$ & 234 & Montage & Montãž ${ }^{2}$ \\
\hline 210 & Laser & Lězar $^{2}$ & 235 & Monument & Monyuměnt ${ }^{l}$ \\
\hline 211 & Light & Layit $^{2}$ & 236 & Motel & Motěl $^{l}$ \\
\hline 212 & List & List $^{l}$ & 237 & Negative & Něgativ ${ }^{l}$ \\
\hline 213 & Load & $\operatorname{Lod}^{l}$ & 238 & Normal & Normãl $^{l}$ \\
\hline 214 & Local & Lokal' ${ }^{\prime}$ & 239 & Nylon & Nãylon ${ }^{l}$ \\
\hline 215 & Logic & Loji:k ${ }^{l}$ & 240 & Office & Ofi:s ${ }^{l}$ \\
\hline 216 & Machine & Maki:na ${ }^{3}$ & 241 & Okay & Okay $^{l}$ \\
\hline 217 & Mafia & Mafiã $^{l}$ & 242 & Opposition & Opozisyon $^{2}$ \\
\hline 218 & Malaria & Malaryã ${ }^{l}$ & 243 & Orchestra & Orkěstra $^{l}$ \\
\hline 219 & Mall & Moíl & 244 & Organ & Organ $^{l}$ \\
\hline 220 & Massage & Masãj $^{2}$ & 245 & Oxygen & Oksiji:n ${ }^{l}$ \\
\hline 221 & Master & Mãstar ${ }^{l}$ & 246 & Ozone & Ozon $^{l}$ \\
\hline
\end{tabular}




\begin{tabular}{|c|c|c|c|c|c|}
\hline N. & English & Kurdish & N. & English & Kurdish \\
\hline 247 & Package & Pakij $^{l}$ & 272 & Potato & Patãta ${ }^{3}$ \\
\hline 248 & Packet & Pãkat ${ }^{l}$ & 273 & Practice & Prãktis $^{2}$ \\
\hline 249 & Page & Payijl & 274 & Press & Prěs $^{l}$ \\
\hline 250 & Pajamas & Bijama $^{3}$ & 275 & Pressure & Prěssar $^{2}$ \\
\hline 251 & Palace & Pãlãs $^{l}$ & 276 & Print & Print $^{l}$ \\
\hline 252 & Pancreas & Pankryãs $^{2}$ & 277 & Printer & Printar $^{l}$ \\
\hline 253 & Panda & Pãndã ${ }^{l}$ & 278 & Process & Prosa $^{3}$ \\
\hline 254 & Panel & Paněí $^{2}$ & 279 & Professional & Profeŝnãlíl \\
\hline 255 & Passport & Pãsaport $^{2}$ & 280 & Profile & Profãyil $^{l}$ \\
\hline 256 & Password & Pãswěrd $^{2}$ & 281 & Program & Progrãm ${ }^{l}$ \\
\hline 257 & Patrol & Patrol $^{2}$ & 282 & Project & Proža $^{3}$ \\
\hline 258 & Pedal & Pãyidar $^{3}$ & 283 & Propaganda & Prupãganda $^{2}$ \\
\hline 259 & Penalty & Panãti $^{2}$ & 284 & Protest & Protěsto $^{2}$ \\
\hline 260 & Petrol & Patrol $^{l}$ & 285 & Protocol & Protokoli ${ }^{l}$ \\
\hline 261 & Photocopy & Fotokopi $^{2}$ & 286 & Pump & Pamp $^{l}$ \\
\hline 262 & Photograph & Fotogrãf ${ }^{l}$ & 287 & Quiz & $\mathrm{Kwiz}^{l}$ \\
\hline 263 & Piano & Piyãno $^{l}$ & 288 & Radar & Rãdãr $^{2}$ \\
\hline 264 & Pizza & Pitzã ${ }^{2}$ & 289 & Radio & Rãdyo $^{2}$ \\
\hline 265 & Plan & Plãn ${ }^{l}$ & 290 & Reform & Riform $^{l}$ \\
\hline 266 & Plaster & Plãstar $^{l}$ & 291 & Regime & Rižěm $^{2}$ \\
\hline 267 & Plastic & Plãsti:k ${ }^{l}$ & 292 & Reportage & Riportãž $^{2}$ \\
\hline 268 & Pliers & Plãyis ${ }^{3}$ & 293 & Restaurant & Rěstorãnt $^{2}$ \\
\hline 269 & Plug & Plãk ${ }^{3}$ & 294 & Robot & Robot $^{l}$ \\
\hline 270 & Police & Poli:s ${ }^{l}$ & 295 & Rocket & Rokět $^{l}$ \\
\hline 271 & Poster & Postar $^{l}$ & 296 & Role & Roíl $^{l}$ \\
\hline
\end{tabular}




\begin{tabular}{|c|c|c|c|c|c|}
\hline N. & English & Kurdish & N. & English & Kurdish \\
\hline 297 & Routine & Roti:n ${ }^{l}$ & 322 & Strategy & Strãti:j² \\
\hline 298 & Saloon & Sãlon $^{l}$ & 323 & Stress & Strěs $^{l}$ \\
\hline 299 & Samovar & Samãwar ${ }^{3}$ & 324 & Studio & Stodyo $^{2}$ \\
\hline 300 & Sample & Sãmpil $^{l}$ & 325 & Style & Stãyil $^{2}$ \\
\hline 301 & Sandwich & Sãndwiĉ $\hat{c}^{l}$ & 326 & Syringe & Srinj $^{2}$ \\
\hline 302 & Satan & Saitãn $^{3}$ & 327 & Tactic & Tãkti:k ${ }^{l}$ \\
\hline 303 & Satellite & Satelãyit $^{2}$ & 328 & Tank & Tãnk $^{l}$ \\
\hline 304 & Satire & Satir $^{3}$ & 329 & Tanker & Tankar $^{l}$ \\
\hline 305 & Sauna & Sãwnã ${ }^{l}$ & 330 & Taxi & Tãksi $^{2}$ \\
\hline 306 & Scan & Skãn ${ }^{l}$ & 331 & Team & Ti:m ${ }^{l}$ \\
\hline 307 & Scanner & Skãnar $^{l}$ & 332 & Tease & Ti: $z^{2}$ \\
\hline 308 & Scenario & Sinãryo $^{l}$ & 333 & Technique & Takni:k ${ }^{2}$ \\
\hline 309 & Scenarist & Sinãrist $^{l}$ & 334 & Technology & Taknalojyã $^{2}$ \\
\hline 310 & Scrap & Sikrãb $^{2}$ & 335 & Telegraph & Talagrãf ${ }^{l}$ \\
\hline 311 & Secretary & Skirtar $^{3}$ & 336 & Telephone & Talafon $^{2}$ \\
\hline 312 & Seminar & Siminãr $^{2}$ & 337 & Telescope & Talěskob $^{2}$ \\
\hline 313 & Shampoo & $\hat{\mathrm{S} a ̃ m p o}{ }^{2}$ & 338 & Television & Talavizyon $^{2}$ \\
\hline 314 & Shoot & $\hat{\text { Sut }}^{l}$ & 339 & Tender & Tandar $^{l}$ \\
\hline & Silo & Sãylo $^{l}$ & 340 & Tennis & Těnis ${ }^{l}$ \\
\hline 316 & Sponsor & Sponsar $^{l}$ & 341 & Terror & Ti:ror ${ }^{2}$ \\
\hline 317 & Spry & Sprãyi $^{2}$ & 342 & Terrorist & Tirorist $^{2}$ \\
\hline 318 & Staff & Stãf ${ }^{l}$ & 343 & Toilet & Tawãlet $^{3}$ \\
\hline 319 & Standard & Stãndard $^{l}$ & 344 & Tomato & Tamãta $^{2}$ \\
\hline 320 & Steak & Stěk $^{l}$ & 345 & Tower & Tãwar $^{l}$ \\
\hline 321 & Steel & Stil $^{l}$ & 346 & Traffic light & Trafik lãyit ${ }^{l}$ \\
\hline
\end{tabular}




\begin{tabular}{|c|c|c|c|c|c|}
\hline N. & English & Kurdish & N. & English & Kurdish \\
\hline 347 & Tragedy & Trãžidyã ${ }^{2}$ & 353 & Wheel & $\mathrm{Wi}: 1^{2}$ \\
\hline 348 & T-shirt & Tiŝěrtt $^{l}$ & 354 & Wireless & Wãyãrlěs ${ }^{2}$ \\
\hline 349 & Tunnel & Tuněĺ $^{2}$ & 355 & Wire & Wãyar $^{2}$ \\
\hline 350 & Video & Vidyo $^{l}$ & 356 & Wrong side & Rong sãyid $l$ \\
\hline 351 & Virus & Vãiros $^{l}$ & 357 & Zigzag & Zi:gzãgl \\
\hline 352 & Vitamin & Vitãmin $l$ & 358 & Zoom & Zum $^{l}$ \\
\hline
\end{tabular}

\section{Notea:}

1. More loanwords can be added to this wordlist hereafter.

2. Symbol conventions are $\left({ }^{I}\right)$ assimilated, $\left({ }^{2}\right)$ partially assimilated, and $\left({ }^{3}\right)$ non-assimilated. 